\title{
Online eLearning for undergraduates in health professions: A systematic review of the impact on knowledge, skills, attitudes and satisfaction
}

\author{
Pradeep Paul George ${ }^{1 *}$, \\ Nikos Papachristou ${ }^{2 *}$, \\ José Marcano Belisario', \\ Wei Wang 4 , Petra A Wark², \\ Ziva Cotic ${ }^{2}$, Kristine Rasmussen ${ }^{2}$, \\ René Sluiter ${ }^{3}$, Eva Riboli-Sasco², \\ Lorainne Tudor Car ${ }^{5}$, Eve Marie \\ Musulanov ${ }^{2}$, Joseph Antonio \\ Molina ${ }^{1}$, Bee Hoon Heng ${ }^{1}$, Yanfeng \\ Zhang ${ }^{4}$, Erica Lynette Wheeler ${ }^{6}$, \\ Najeeb Al Shorbaji ${ }^{5}$, Azeem \\ Majeed $^{5}$, Josip Car ${ }^{1,7}$

\footnotetext{
${ }^{1}$ Health Services and Outcomes Research, National Healthcare Group, Singapore

${ }^{2}$ Global eHealth Unit, Department of Primary Care and Public Health, School of Public Health, Imperial College London, London, UK

${ }^{3}$ Department of Health Evidence, Radboud University Nijmegen, Nijmegen, The Netherlands

${ }^{4}$ Department of Integrated Early Childhood Development, Capital Institute of Pediatrics, Chaoyang District Beijing, P.R. China

${ }^{5}$ Department of Primary Care and Public Health, School of Public Health, Imperial College London, London, UK

${ }^{6}$ Knowledge, Ethics and Research, World Health Organization, Geneva, Switzerland

${ }^{7}$ Health Services and Outcomes Research Programme, Lee Kong Chian School of Medicine, Imperial College \& Nanyang Technological University, Singapore

* Joint first authors
}

Background Health systems worldwide are facing shortages in health professional workforce. Several studies have demonstrated the direct correlation between the availability of health workers, coverage of health services, and population health outcomes. To address this shortage, online eLearning is increasingly being adopted in health professionals' education. To inform policy-making, in online eLearning, we need to determine its effectiveness.

Methods We performed a systematic review of the effectiveness of online eLearning through a comprehensive search of the major databases for randomised controlled trials that compared online eLearning to traditional learning or alternative learning methods. The search period was from January 2000 to August 2013. We included articles which primarily focused on students' knowledge, skills, satisfaction and attitudes toward eLearning and cost-effectiveness and adverse effects as secondary outcomes. Two reviewers independently extracted data from the included studies. Due to significant heterogeneity among the included studies, we presented our results as a narrative synthesis.

Findings Fifty-nine studies, including 6750 students enrolled in medicine, dentistry, nursing, physical therapy and pharmacy studies, met the inclusion criteria. Twelve of the 50 studies testing knowledge gains found significantly higher gains in the online eLearning intervention groups compared to traditional learning, whereas 27 did not detect significant differences or found mixed results. Eleven studies did not test for differences. Six studies detected significantly higher skill gains in the online eLearning intervention groups, whilst 3 other studies testing skill gains did not detect differences between groups and 1 study showed mixed results. Twelve studies tested students' attitudes, of which 8 studies showed no differences in attitudes or preferences for online eLearning. Students' satisfaction was measured in 29 studies, 4 studies showed higher satisfaction for online eLearning and 20 studies showed no difference in satisfaction between online eLearning and traditional learning. Risk of bias was high for several of the included studies.

Conclusion The current evidence base suggests that online eLearning is equivalent, possibly superior to traditional learning. These findings present a potential incentive for policy makers to cautiously encourage its adoption, while respecting the heterogeneity among the studies.

\section{Correspondence to:}

A/Prof J Car

3 Fusionopolis Link

\#03-08Nexus@one-north

Singapore 138543

josip.car@imperial.ac.uk 
Health care workers are central to any health system; their activities are aimed at enhancing the health of the community, nation or region in general. However, these professionals are distributed unevenly across the globe; countries with lower relative need have the highest numbers of health workers, while those with the greatest burden of disease have a much smaller health workforce. The health worker crisis is at its worst in sub-Saharan Africa and Asia. Incidentally, countries in this region are facing a double burden of both infectious and non-communicable diseases [1], and they lack the funds, technology, infrastructure and trained health workers needed to provide basic health care service [2]. At this juncture; the WHO estimates a shortage of 7.2 million doctors, nurses, midwives and other health care professionals worldwide [3]. Addressing this shortfall in health care professionals through training requires a substantial investment.

Meanwhile, the Internet and the development of information technologies have revitalized the exchange of information and training worldwide. Consequently, eLearning is used increasingly in medical and health professional education, to tackle the global shortage of health workers. eLearning is "an approach to teaching and learning, representing all or part of the educational model applied, that is based on the use of electronic media and devices as tools for improving access to training, communication and interaction and that facilitates the adoption of new ways of understanding and developing learning" [4]. It does not only differ from traditional learning (ie, face-to-face learning that takes place in a classroom environment) in the medium by which learning is delivered [5], but also affects the teaching and learning approaches used. eLearning can take the form of a full eLearning approach, which is entirely driven by technology, or be a mix of the traditional and fully computer-based methodologies (blended learning). Blended learning might be more suitable for health care training because of the need to combine hands-on skillsbased training at a practical level as well as self-directed learning [6-10].

Lately, eLearning has started to make way into the developing countries and is believed to have huge potential for governments struggling to meet a growing demand for education while facing an escalating shortage of teachers [11]. However, in both the developing and non-developing countries, network connectivity and bandwidth availability are the key obstacles to the effective delivery of online eLearning $[5,12]$. Despite this, eLearning presents many opportunities for universities, including the reduction of the delivery costs [13], increased scalability [14], improved access and availability by removing geographical and temporal barriers and allowing access to relevant experts and novel curricula [15].
Online eLearning represents a further evolution of computer-assisted or computer based or offline eLearning and is an important tool in medical training and may transform the way medicine is taught [16]. In the recent years, nearly all medical schools in the USA and Canada employ online course materials [17]. eLearning could be full or blended, full eLearning can be distributed geographically and/or temporally, and communication between student and teacher is handled electronically. This manuscript focuses on online eLearning; systematic review of offline eLearning is published in a parallel article [18].

Online eLearning approaches varied widely in configuration (tutorial, asynchronous discussion, live conferencing, etc.), instructional methods (eg, practice exercises, cognitive interactivity) and presentation [17]. The majority of reviews of effectiveness of online eLearning included observational studies with several methodological deficiencies $[16,17,19-22]$. This systematic review aims to evaluate the effectiveness of online eLearning from randomised controlled trials conducted among undergraduate health professionals, specifically looking at its impact on students' knowledge, skills, attitudes and satisfaction.

\section{METHODS}

We conducted a systematic review following the Cochrane methodology [23].

\section{Search methods for identification of studies}

Electronic searches. We limited our electronic searches to records published on or after the year 2000 in order to highlight recent developments. We developed a search strategy for MEDLINE (OvidSP) using a combination of keywords and MeSH terms that captured the types of intervention and the types of participants under evaluation in this systematic review (Table 1 ). We adapted the search strategy for use in EMBASE (OvidSP), PsycINFO (Ovid SP), Cochrane Central Register of Controlled Trials (CENTRAL), Web of Science, and Educational Resources Information Center (ERIC) (ProQuest). Where available, we used validated methodological filters to limit our searches to Randomised Controlled Trials (RCTs) and cluster RCTs (cRCTs). We ran the searches in August 2013.

Searching other resources. We checked reference lists of the included studies and systematic reviews of the literature identified by our electronic searches for additional studies.

\section{Inclusion criteria}

Types of studies and participants. We included studies published in any language on students of (i) undergraduate, health-related university degrees; or (ii) basic, health- 
Table 1. Search strategy for use in MEDLINE (Ovid SP)*

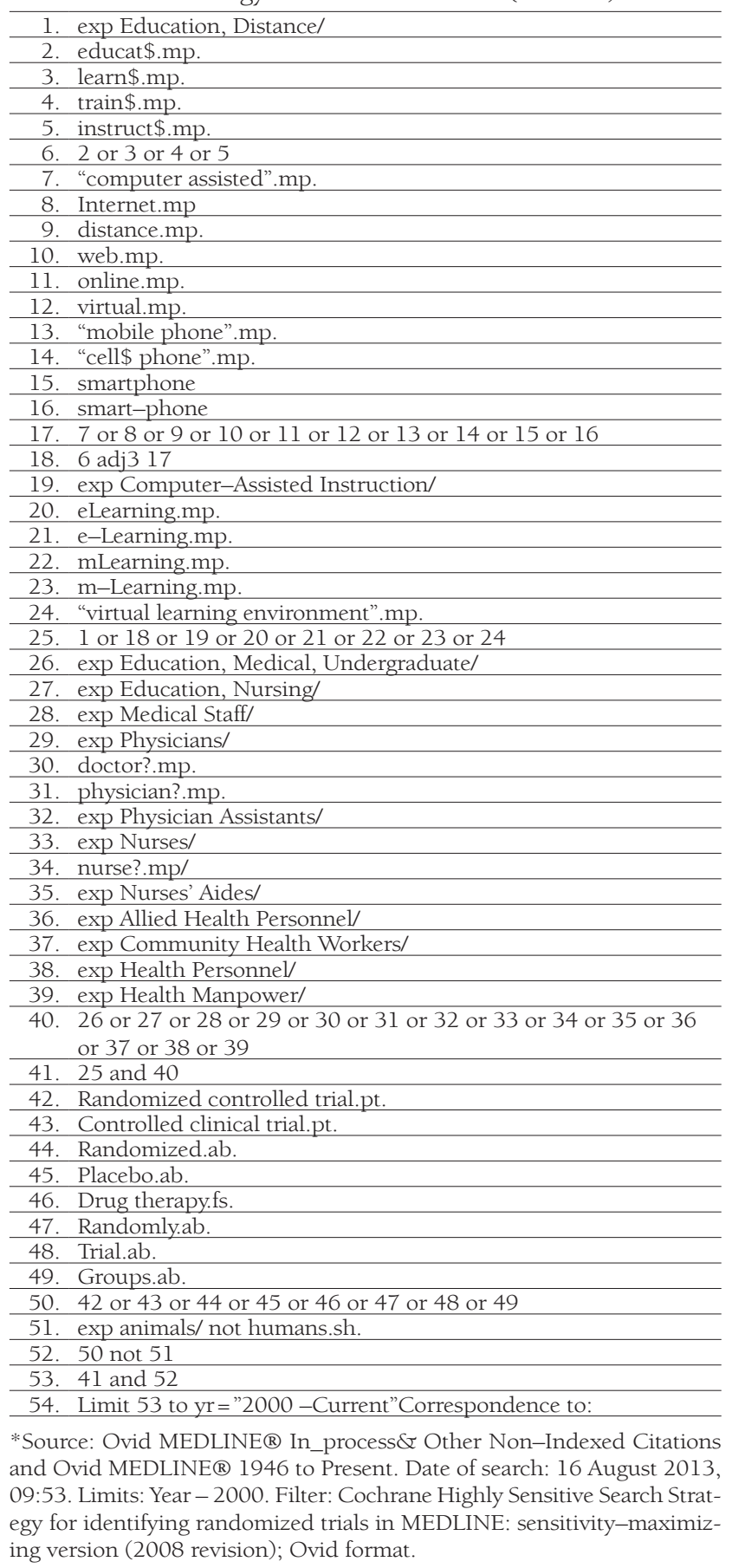

related vocational training programmes. We defined undergraduate education or basic vocational training as any type of study leading to a qualification that: (i) is recognised by the relevant governmental or professional bodies of the country where the studies were conducted; and (ii) entitles the qualification-holder to apply for entry level positions in the health care workforce. For this reason, graduate medical education courses from the USA were included.

We considered studies on candidates for and holders of the qualifications listed in the Health Field of Education and Training of the International Standard Classification of Ed- ucation (ISCED-F) [24], except studies on students of traditional and complementary medicine. We hence included students reading dental studies, medicine, nursing and midwifery, medical diagnostic and treatment technology, therapy and rehabilitation, or pharmacy. Medicine and dentistry were classified under the umbrella term allied health professions.

Types of intervention. First, we conducted a systematic mapping of the types of technologies used by the included studies to deliver the learning materials, through which we identified 6 broad categories of eLearning interventions, based on the technologies employed: (1) Offline computer-based eLearning, (2) Online and local area networkbased eLearning, (3) Psychomotor skills trainer, (4) Virtual reality environments, (5) Digital game-based learning and (6) mLearning. We allocated each included study to the category that fitted the study best. Please refer to Online Supplementary Document for a definition of these categories.

We only included studies in which online eLearning interventions were used to deliver the learning content, studies were categorized as online eLearning if the delivery of the learning content was done through the internet or intranet connections. Only studies that compared online eLearning or blended eLearning methods to: (i) traditional learning; (ii) an alternative eLearning or blended learning method; or (iii) no intervention was eligible for inclusion. These studies could either be studies where eLearning was the sole means by which the intervention was delivered or where eLearning was part of a complex, multi-component intervention.

Types of outcome measures. To be eligible for inclusion, studies had to report at least 1 of the following primary or secondary outcomes.

Primary outcomes: (1) Students' knowledge, measured using any validated or non-validated instrument (eg, preand post-test scores, grades, perceived knowledge survey scores); (2) Students' skills, measured using any validated or non-validated instrument (eg, pre-and post-test scores, time to perform a procedure, number of errors made whilst performing a procedure, perceived up-skilling); (3) Students' satisfaction and attitudes towards eLearning, measured using any validated or non-validated instrument (eg, self-efficacy, satisfaction, acceptability).

Secondary outcomes: (1) Health economic properties of the interventions (eg, implementation cost, return on investment); (2) Adverse and/or unintended effects of eLearning (eg, potential feelings of depression and loneliness, dropout risks [25] and "computer anxiety" [26]).

We only considered studies to have measured students' satisfaction and attitudes towards eLearning if they met all of the following criteria: (i) they compared the differences be- 
tween intervention and control groups for these outcomes; (ii) the content of the survey questionnaires related to the teaching method (ie, eLearning method, blended learning, or traditional learning); and (iii) the adjectives used in the survey questionnaires accurately described attitudes and/ or satisfaction.

\section{Study selection and data collection}

The study selection process is summarised in the PRISMA flow diagram (Figure 1). In brief, we screened the titles and abstracts of the citations identified by our electronic and manual searches to identify potentially relevant studies, of which we assessed the full-text report to ensure they meet the inclusion criteria we specified. Review authors completed these tasks independently and met to compare their results and reach consensus.

Every selected study was allocated to a pair of review authors, with 10 review authors participating in total. Each review author independently extracted data from the included studies using the structured data extraction sheet shown in Online Supplementary Document.

Each pair of reviewers compared their completed data extraction forms and any discrepancies between review authors' results were resolved through discussion; if no agreement could be reached, a third review author acted as an

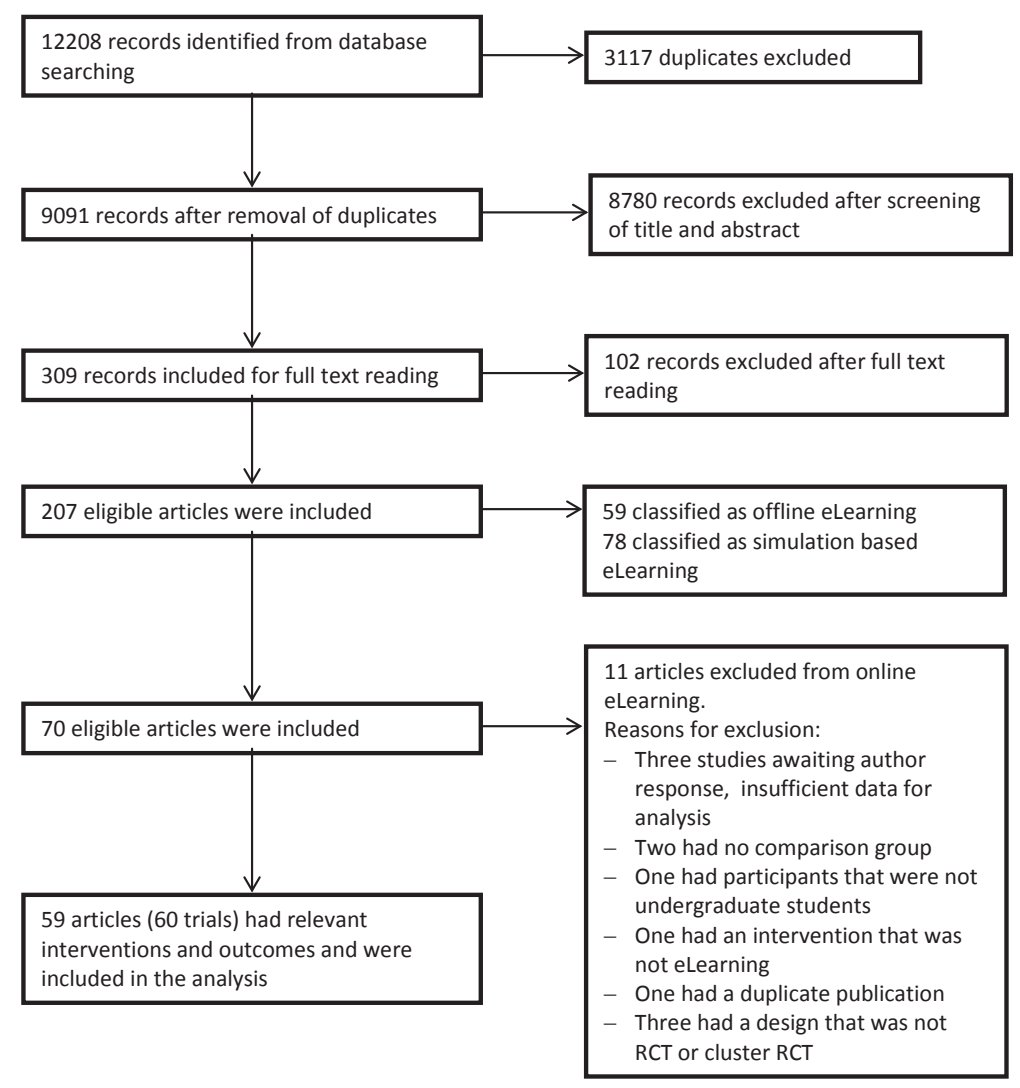

Figure 1. Flowchart of the studies included in the review. arbiter. Because 10 review authors participated in the data extraction process, some categories were interpreted differently by some reviewers. Therefore, 3 reviewers went over the entire data extraction again to ensure uniformity.

We contacted authors of studies containing incomplete data to request the missing information. Some authors did not reply to our request for additional information, whilst other authors did not know the answer to our questions. For 1 study the response obtained from the author resulted in the subsequent exclusion of the study from the systematic review.

\section{Assessment of risk of bias in included studies}

During the data extraction process, we assessed the risk of bias at the outcome level using tools recommended by the Cochrane Collaboration [23]. For RCTs, we did so across the domains of (1) random sequence generation, (2) allocation concealment, (3) blinding of participants and personnel, (4) blinding of outcome assessment, (5) incomplete outcome data, (6) selective outcome reporting, and (7) other bias including the comparability of intervention and control group; characteristics at baseline; validation of outcome assessment tools; reliability of outcome measures; and protection against contamination.

We assessed the risk of bias for cRCTs across the domains of (1) recruitment bias, (2) baseline imbalances, (3) loss of clusters and (4) incorrect analysis. For each study, 2 reviewers independently categorised each domain as low, high or unclear risk of bias.

\section{Summarising the data}

We qualitatively compared the characteristics of the participants and of the interventions between the included studies to determine the feasibility of conducting a meta-analysis. Because of substantial clinical, educational, content and methodological heterogeneity we did not conduct a meta-analysis. Instead, we adopted a thematic summary approach [27].

\section{RESULTS}

12208 reports were identified from database screening of which 309 were retrieved for fulltext evaluation of which 207 studies met the inclusion criteria (Figure 1). Fifty-nine articles [25-82] complied with the term internet and local area network or online eLearning (see Online Supplementary Document for detailed description) and were included in the 
analysis. One study [83] involved students in 2 consecutive RCTs that were analysed separately (Ainsworth 2012A, Ainsworth 2012B). Thus the total number of evaluated trials was 60 .

\section{Included studies}

All studies were published in peer reviewed journals between 2000 and 2013 except 1 dissertation [81]. All included studies were parallel RCTs or cRCTs. The included number of RCTs and cRCTs suggests an increase in the number of publications after 2007 as eighteen of the included studies (30\%) have been published between 2000 up and 2007 (ie, 8 years). The remaining 42 studies (70\%) have been published in the shorter time interval between 2008 and mid 2013 (ie, 5.5 years). Out of all 60 included studies, 33 studies investigated eLearning in the field of medicine $[26,28,32,34-36,38-41,44,45,49,50,54,58-$ $62,64-70,72,75,77,78,80,82]$. Eleven of the articles [25,2 $7,33,42,43,53,56,74,76,79,83]$ were exclusively from nursing, $3[55,57,81]$ were within the field of physical therapy, whereas 3 other studies within pharmacy $[30,31,71]$. Nine studies [29,37,46-48,51,63,73] investigated eLearning for dentistry students. Additionally, 1 article [52] dealt with medicine, nursing, and physical therapy while the remaining study recruited university students, but did not define their discipline [81].

\section{Participant characteristics}

The total number of participants included across all trials was 6750 participants. The study with the smallest control group had 10 participants [77] whereas the largest control group had 249 participants [55]. The study with the small- est intervention group had 10 participants [33], while the largest intervention group had 349 participants [55]. Most studies were conducted among undergraduate university students apart from 9 studies [27,29-31,33,42,53,54,79] that investigated the effect of network-based eLearning for vocational training. Out of the 20 (33\%) studies $[30,32,33,40,45,47-49,52,53,55,57,64,65,71,73,75$, 76,83 ] that specified the age of the students, the lowest mean age of participants in a control group was 20.0 years [55] and the oldest was 30.0 years [76]. The lowest mean age in an intervention group was 19.9 years [75] and the highest was 30.0 years [76].

\section{Intervention characteristics}

Fifty studies compared eLearning to traditional learning, and 10 studies $[26,35,36,45,46,61-63,66,74]$ compared 1 mode of eLearning to another mode of eLearning. The duration of exposure ranged from 9.05 minutes to 9 months [83]. Most of the studies (51 out of $60,85 \%$ ) were conducted exclusively in high income countries. Seven studies were conducted solely in low- to middle-income countries: 2 in Brazil [25,26]; 2 in China [38,56]; 1 in Thailand [33]; and 2 in the Chinese Taipei [27,42]. One study [52] was conducted simultaneously in Brazil and the USA (Figure 2).

The majority of the studies used a website to present the learning material to the participants as part of their intervention [25-34,37-46,48-66,68-80,82,83]. Three studies $[35,36,47]$ used a spaced education intervention, ie, an intervention in which the educational exposures are spaced and repeated over time [35]. In these studies the learning material was presented via email on a regular basis $[35,36$,

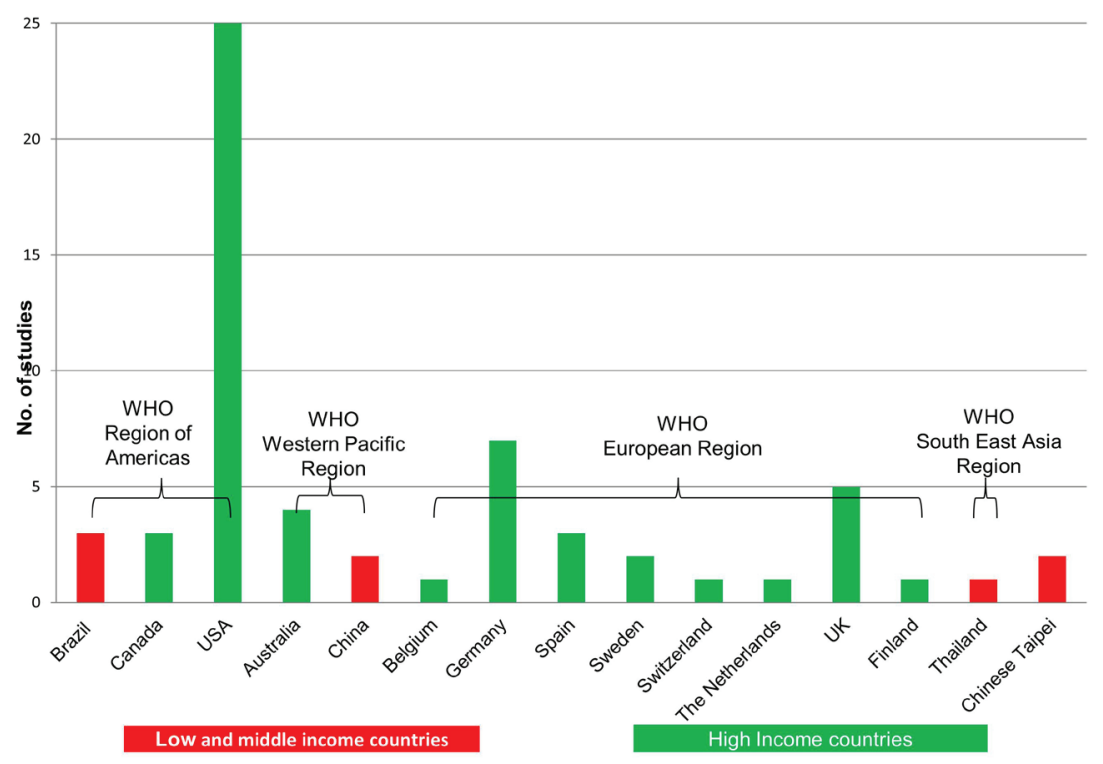

Figure 2. Country of origin of included, examined studies for low- and middle-income and high income countries separately. 
47]. One study used video conference lectures as an intervention [67], and 1 study used a visual concept map [81].

\section{Primary outcomes}

Students' knowledge assessment. The knowledge gained from the exposure to the intervention was assessed in a number of different ways in the included studies. Overall, 53 [25-27,29-33,35-46,48-52,54,56-67,69,70,72-83] out of the 60 studies looked at a knowledge as an outcome. Nineteen of these studies $[25,32,35,40,43,45,48-50,56$, $57,60,69,72,74,75,77,80,82]$ used only multiple choice questions (MCQs) to test students' knowledge and understanding. Six studies used MCQs as a knowledge assessment tool together with an adaptive spaced test [36], gap text questions [51], matching and short answer questions [61], open ended and true/false questions [64], short essay questions [81] and a key features test [59].

Seven studies reported using test questions $[31,39,40,44,67$, $70,78]$ to assess knowledge of study participants. Six other studies used open ended $[30,33,63,66]$ or Likert type questionnaires [29] or even "fill in the blank" questions [73]. The rest of the studies measured students' knowledge gain via other testing means including general numeracy tests [83]; written exams [41,46,58,65]; independent observers' assessment [79]; cognitive assessment instruments [54]; surgical knowledge test scores [76]; a Diagnostic Thinking Inventory and individual students' performance in solving clinical reasoning problems [38]; a modified version of the Dartmouth Sleep Knowledge and Attitudes survey [62]; an interactive evaluation about melanoma [26]; an orthodontic examination form for each patient [37]; or some form of a knowledge assessment scale or checklist $[42,52,68]$.

Students' skills assessment. Skills were evaluated in 16 studies [28-30,32-34,39,42,53,55,57,63,68,69,71,72] using various methods to assess the outcome. Nine studies $[33,34,42,55,63,68,71,72]$ used a rating scale and/or checklists (eg, an OSCE) to assess clinical skills. One study [53] used a search skills test, another 1 [29] a Likert type questionnaire while 3 studies evaluated students skills through written assessments such as data collection sheets [30], written case analysis [41] and open questions on standardised tasks [32]. Finally, 1 study [28] measured the degree of new skills acquisition by using a self-assessment report whilst another [39] measured the time that students made to complete the assigned exercise.

Students' satisfaction and attitudes towards eLearning. Feedback from students assessed as their attitude towards the eLearning intervention was reported as an outcome in a total of 14 studies $[28,29,32,33,43,45,48,49,54-56,63$, 64,72 ]. In all of these, students' attitude was measured by questionnaires.
Student satisfaction was considered as an outcome in 33 studies [25,32-34,37-41,43,46-48,50-52,55,57-61,64$66,68,69,73-76,80,82]$. Seventeen of these studies $[33,34,38,40,51,52,55,57,59,61,64-66,68,73,75,76]$ mentioned that student satisfaction was evaluated with Likert scale questionnaires. The 16 remaining studies comparing student satisfaction among the students $[25,32,37,39$, $41,43,46-48,50,58,60,69,74,80,82]$ used different types of questionnaires or surveys without mentioning the use of Likert scales.

\section{Secondary outcomes}

Cost-effectiveness of the eLearning interventions. Cost-effectiveness or cost-benefit or cost-utility of eLearning interventions were not assessed in any of the studies, however, some of the studies mentioned several financial and resource related elements of eLearning.

Buzzell et al. [54] mentioned that in the future many experts would be involved in content generation for their respective disciplines and that content could be shared online among their disciplines. Thus the online content development and delivery would not need the involvement of many faculty at all stages of content development and in turn educational institutions would be cost efficient. Stain et al. [67] mentioned that the costs of setting up videoconferencing were comparable to the costs of live lectures after an initial hardware investment of less than US\$10000. Stewart et al. [68] cited a paper saying that reduction of instructor training time, labour costs and institutional infrastructure could result in significant cost-efficiency. Toumas et al. [71] mentioned in the discussion that using the Internet leads to "reduced costs in terms of tutor-led workshops and is more efficient, enabling more complex topics to be covered in workshops". Hauer et al. [34] deduced that the video cases were cheaper than the mini-CPX (Clinical Performance Evaluation) examination they used. An in-person examination of a class of 150 students cost approximately US\$ 5400, which did not yet include Clinical Skills Centre maintenance costs, costs of case development and payment of Centre staff. In contrast, plain technologies as video cases were produced at a total cost of US\$ 2200. Besides, the video cases could be reused freely, whereas the in-person mini-CPX requires annual purchase of a license.

In contrast, Fleming et al. [73] mentioned that the development of web-based or Computer Assisted Instruction is expensive in terms of time and energy spent. Phadtare et al. [52] made a general comment on the potential lack of necessary infrastructure and "new" costs associated with online courses.

Adverse and/or unintended effects of eLearning. Adverse or unintended events of the eLearning intervention were not reported in any of the studies. 


\section{Excluded studies}

Initially, 65 studies were categorised as online eLearning studies. We reclassified 2 studies $[84,85]$ as non-networked computer-based because their eLearning interventions could be fully functional even without network technologies' support. Three studies [86-88] were excluded because of insufficient data while another [35] was excluded as a duplicate paper. Seven studies [89-95] were excluded during the data extraction process, just before the analysis, because they met 1 or more of the exclusion criteria. Four of these 7 studies $[91,92,94,95]$ were excluded because their study design was not a parallel or CRCT eg, a cross-over design [94]. Two studies [89,93] were excluded because they did not include comparison groups for the eLearning intervention eg, 2 different blended teaching methods using a common eLearning intervention in exactly the same way [93]. Finally, 1 study [90] used an eLearning intervention which was considered ineligible for our study ie, electronic voting during the lecture [90].

\section{Risk of bias in the included parallel RCTs}

Thirty-one of the studies were considered to be at high risk of bias. $[25,33,34,36,38-41,44,49-51,53,55,57,60,62-$ $64,69,70,72,74-77,79-81,83]$. Twenty-nine of the studies $[26,30,32,35,43,48,52,54,56,59,61,65-67,73,78]$ had 1 or more categories classified as an unclear risk of bias, especially regarding the allocation of participants to intervention groups. There was only 1 study [47] with all the categories classified as low risk of bias (Figure 3 and 4). Risk of bias is described in detail in the Supplementary Online

\section{Document.}

\section{Effects of online eLearning interventions}

The 60 randomized trials included in our review assessed the effectiveness of online eLearning interventions in terms of knowledge, skills, attitudes and satisfaction. The findings were based on comparisons between online eLearning and traditional learning or between various modes of online eLearning. A study may have compared more than 1

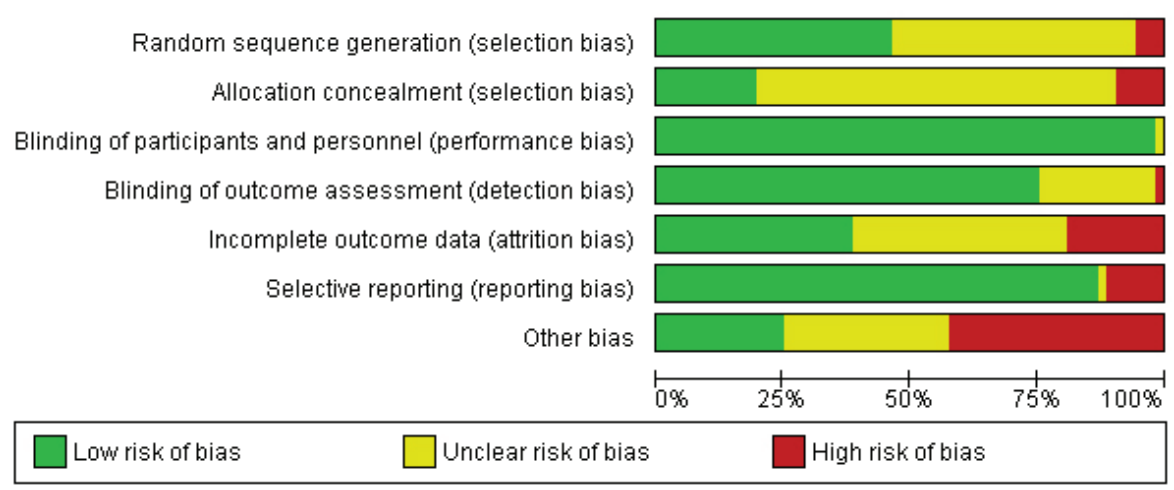

Figure 3. Overall risk of bias graph.
Figure 4. Risk of bias for each individual parallel randomised controlled trial (RCT) separately.

\begin{tabular}{|c|c|c|c|c|c|c|c|}
\hline & 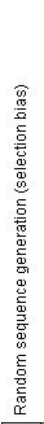 & 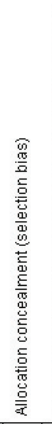 & 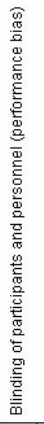 & 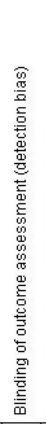 & 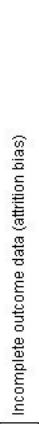 & 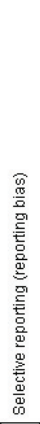 & 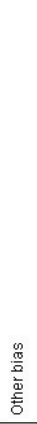 \\
\hline Ainsworth 2012a[83] & + & + & + & $\bullet$ & + & $\theta$ & $\theta$ \\
\hline Ainsworth $2012 \mathrm{~b}[83]$ & ๑) & 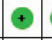 & + & + & + & $\theta$ & $?$ \\
\hline royo-Morales $2012[57]$ & + & $?$ & + & $?$ & $\odot$ & 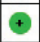 & ○ \\
\hline Beeckman 2008[79] & ( & $?$ & + & + & 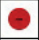 & + & $?$ \\
\hline Brettle 2013[53] & $\bullet$ & $?$ & $\odot$ & $?$ & $\odot$ & $\odot$ & $?$ \\
\hline Buzzell 2002[54] & \begin{tabular}{|l|}
$?$ \\
\end{tabular} & $?$ & $\odot$ & $\bullet$ & $?$ & 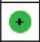 & $\odot$ \\
\hline Chao 2003[26] & \begin{tabular}{|l|}
$?$ \\
\end{tabular} & $?$ & $\odot$ & $\bullet$ & $\odot$ & $\odot$ & $?$ \\
\hline Chen 2007[81] & + & $\odot$ & + & - & $?$ & $\odot$ & $\odot$ \\
\hline C-Villanueva $2012[55]$ & 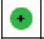 & $?$ & + & + & $?$ & + & ○ \\
\hline Erickson 2003[30] & $\odot$ & $?$ & $\odot$ & $\odot$ & $\odot$ & + & $?$ \\
\hline Fernandez 2011 [76] & $?$ & $?$ & + & + & ○ & + & ○ \\
\hline Fleming 2003[73] & 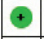 & $?$ & $\odot$ & ๑) & $?$ & + & $?$ \\
\hline Friedl 2006[32] & $?$ & $?$ & + & (†) & + & + & $?$ \\
\hline Frith $2003[74]$ & $?$ & 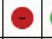 & $\odot$ & $\odot$ & $\odot$ & $\Theta$ & ○ \\
\hline Gerdprasert $2011[33]$ & $?$ & $?$ & $\odot$ & $?$ & $\odot$ & $\odot$ & $?$ \\
\hline Hauer 2009[34] & $?$ & $?$ & $\odot$ & $?$ & ○ & $\odot$ & ○ \\
\hline Jenkins $2008[78]$ & $\odot$ & $?$ & $\odot$ & $\odot$ & $\odot$ & $\odot$ & $?$ \\
\hline Juliani 2011[25] & $\odot$ & ○ & $\odot$ & ๑) & $?$ & $\odot$ & ○ \\
\hline Kandasamy $2009[80]$ & ๑) & + & $\odot$ & $\odot$ & ○ & + & $?$ \\
\hline Kerfoot 2008[35] & $?$ & $?$ & $\odot$ & + & $\oplus$ & $\odot$ & $?$ \\
\hline Kerfoot 2010[36] & $?$ & $?$ & + & + & $?$ & + & $\theta$ \\
\hline Komolpis 2002[37] & $?$ & $?$ & $\odot$ & + & $\odot$ & $\odot$ & $\odot$ \\
\hline Lee 2010[38] & ๑ & $?$ & + & + & + & 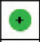 & $\theta$ \\
\hline Leong 2003[39] & ○ & $?$ & + & $?$ & + & + & $\theta$ \\
\hline Lewis $2011[40]$ & ○ & $\theta$ & + & $\odot$ & $?$ & + & ○ \\
\hline Lipman 2001 [41] & $?$ & $?$ & $\odot$ & $\odot$ & $\odot$ & $\odot$ & $?$ \\
\hline Maag 2004[43] & $?$ & $?$ & $\odot$ & + & $\odot$ & + & $\odot$ \\
\hline Mahnken 2011[44] & - & $\theta$ & $\odot$ & 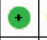 & $?$ & $\odot$ & $\odot$ \\
\hline Mattheos 2004[46] & $\odot$ & $?$ & $\odot$ & + & $\odot$ & $\odot$ & $?$ \\
\hline Nkenke 2012[47] & $?$ & $?$ & $?$ & $?$ & + & $\odot$ & $\odot$ \\
\hline Nkenke 2012a[48] & $\odot$ & $\odot$ & $\odot$ & $\odot$ & $\odot$ & + & + \\
\hline Ochoa 2008[49] & ๑ & $\odot$ & $\odot$ & $\odot$ & $?$ & $\odot$ & ○ \\
\hline Palmer 2008[50] & $?$ & $?$ & + & $?$ & $?$ & $\odot$ & ○ \\
\hline Peroz 2009[51] & $?$ & $?$ & $\odot$ & + & $?$ & + & ○ \\
\hline Phadtare 2009[52] & 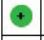 & $\odot$ & $\odot$ & $?$ & $?$ & $\odot$ & $?$ \\
\hline Raupach 2009[59] & $?$ & $?$ & $\odot$ & $\odot$ & $\odot$ & $\odot$ & $\odot$ \\
\hline Raupach $2010[60]$ & $?$ & $?$ & $\odot$ & $\odot$ & $\odot$ & $\odot$ & ○ \\
\hline Ricks 2008[77] & $\odot$ & $?$ & $\odot$ & 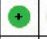 & $\odot$ & $?$ & $\odot$ \\
\hline Romanov 2006[61] & $?$ & $?$ & $\odot$ & $\odot$ & $?$ & $\odot$ & $\odot$ \\
\hline Salas 2013[62] & $?$ & $?$ & + & $\odot$ & $?$ & + & $\odot$ \\
\hline Schittek 2005[63] & $?$ & $?$ & + & + & $?$ & + & 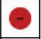 \\
\hline Smits 2012[64] & + & $?$ & + & $?$ & ○ & + & + \\
\hline Spickard 2002[65] & 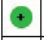 & $\odot$ & $\odot$ & $\odot$ & $?$ & $\odot$ & $\odot$ \\
\hline Spickard 2004[66] & $?$ & $?$ & $\odot$ & + & $\odot$ & + & $\odot$ \\
\hline Stain 2005[67] & $?$ & $?$ & $\odot$ & $?$ & $?$ & $\odot$ & $?$ \\
\hline Stewart $2013[68]$ & $\odot$ & $\odot$ & + & 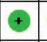 & $?$ & $\odot$ & $?$ \\
\hline Stolz 2012[69] & + & $?$ & $\odot$ & $?$ & $?$ & $\odot$ & $\theta$ \\
\hline Subramanian $2012[70]$ & $?$ & $?$ & $\odot$ & + & $\odot$ & $\odot$ & $?$ \\
\hline Succar 2010[82] & $?$ & $?$ & $\odot$ & + & $?$ & 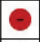 & $\odot$ \\
\hline Truncali 2011[72] & $?$ & $\theta$ & $\odot$ & $?$ & $\odot$ & $\odot$ & $\odot$ \\
\hline 19[56] & $\odot$ & $?$ & $\odot$ & $\oplus$ & $?$ & + & $\odot$ \\
\hline Yeung $2012[75]$ & 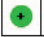 & + & $\odot$ & $\oplus$ & $?$ & + & 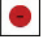 \\
\hline
\end{tabular}


outcome between groups, and each outcome may have been assessed in multiple ways. For example, a study which compared students' acquisition of skills may have assessed skills in terms of the student's performance on a global rating scale, the ability to perform a specific procedure, as well as the ability to comply with the requirements in a checklist. As a result, the number of comparisons made across studies for a particular outcome may exceed the number of studies which reported on that outcome. Only 2 studies $[32,33]$ measured all specified outcomes of knowledge, skills, attitudes and satisfaction.

The studies were split into 2 research themes evaluating the impact of eLearning interventions for undergraduate health care education: traditional learning vs online eLearning, and online eLearning vs online eLearning.

\section{Traditional learning vs online eLearning}

Fifty of the 60 included studies (83\%) compared online eLearning with traditional learning. [25,27-34,37-44,47$58,60,64,65,67-73,75-83]$. Table 2 presents the summary of the findings of the individual studies. Further description of the nature of the interventions is in the Online

\section{Supplementary Document.}

Students' knowledge. Amongst the 60 studies which compared online eLearning with traditional learning, knowledge was assessed in 43 RCT studies (86\%) [25,27,29$31,37-44,48-52,54,56-60,64,65,67,69,70,72,73,75-83]$ and 7 cRCT studies [27-29,31,42,58,71].

Twelve studies (27\%) assessing knowledge gain demonstrated significantly higher knowledge gains for students assigned to the online eLearning compared to those exposed to traditional learning $[31,41,49,51,52,56,60,70,72$, $77,79,83]$. Outcome measures for these studies were based on test items or questions [31,70], written case analyses [41], MCQs [50,51,56,60,72,77], the Six-subgroup Quality Scale (SSQS) [52], a general numeracy test [83] and independent assessments by evaluators [79]. The sample size of these studies ranged from 39 to 1475 . Six of these 12 studies were conducted on medical students $[41,49,60,70$, 72,77], 3 among nursing students [56,79,83], 1 among dentistry students [51], 1 among pharmacy students [31], while 1 study [52] was conducted among medicine, nursing, and physical therapy students. Five of these studies used full online eLearning as the main intervention $[49,52$, $70,77,79]$ whereas 7 used blended learning $[31,41,51,56,60$, $72,83]$.

Post-intervention knowledge was not significantly different between eLearning and traditional learning in 24 (48\%) of the included studies $[25,32,33,37,38,42-44,48,50,54$, $57-59,64,65,69,73,75,76,78,81,83]$. Three studies $[27,30$, 39] showed mixed results ie, favouring the intervention, control or neither 1 depending on the specific indicator of knowledge being assessed. In 1 (2\%) study [82] knowledge was assessed but not tested for statistically significant differences between the intervention groups.

Finally, there were 3 studies $[29,30,80]$ that demonstrated significantly higher knowledge gains for students assigned to traditional eLearning compared to those exposed to online eLearning. Two of these studies $[29,80]$ used full online eLearning as the main intervention while the other 1 [40] used blended learning.

Students' skills. Overall, 15 studies - 11 RCTs [30,32$34,39,53,55,57,68,69,72]$ and 4 cRCTs $[28,29,42,71]$ measured skills as outcome.

Of the studies that evaluated differences in skill acquisition, $6(40 \%)$ found significantly greater skill acquisition amongst students assigned to online eLearning $[33,34,42,57,71,72]$. The number of participants included in these studies ranged from 44 to 303 . Two of these studies were conducted in medical students [34,72], 2 in nursing students [33,42], 1 in physiotherapy students [57] and 1 in pharmacy students [71]. Four of these studies used traditional learning as their main intervention $[34,42,57,71]$, whereas 2 used blended learning as the main intervention $[33,72]$.

Three studies (21\%) did not detect a significant difference in skill acquisition between groups $[39,53,55]$. One study [30] showed mixed results ie, favouring the online eLearning or the traditional learning group depending on the specific indicator of skills being assessed. This study had 3 groups, comparing pharmacy students' knowledge and ability to assess metered-dose inhaler (MDI) after a lecture based tutorial, a web-based tutorial and being provided no teaching on the topic at all. Finally, there was 1 study [69] that demonstrated significantly higher skill gains for students assigned to traditional learning compared to those exposed to online eLearning. This study used full eLearning as the main intervention.

Students' attitudes and satisfaction. Twelve studies (24\%) - 10 RCTs $[32,33,43,48,49,54-56,64,69,72]$ and 2 cRCTs $[28,29]$ - assessed attitudes as an outcome of the intervention through questionnaires.

Eight of these studies [29,32,33,43,49,50,54,56] (67\%) did not find a statistically significant difference between the 2 types of learning methods, or the study showed mixed results for online eLearning vs traditional learning depending on the test evaluated. Three studies $[28,55,72]$ assessed attitude, but did not test for statistically significant differences between the intervention groups. None of the studies reported a significant result on student attitudes favouring online eLearning interventions.

The remaining study (8\%) [64] reported more positive attitudes towards the intervention in the traditional learning groups. This study used full online eLearning as the main intervention. 
Table 2. Summary of findings from the 50 studies which compared online eLearning with traditional learning

\begin{tabular}{|c|c|c|c|c|c|c|c|c|}
\hline Study & DISGIPLINE & KNOWLEDGE & SkiLs & Attitude & $\begin{array}{l}\text { SATISFAG- } \\
\text { TION }\end{array}$ & $\begin{array}{l}\text { No. OF } \\
\text { PARTICIPANTS }\end{array}$ & INTERVENTION DELIVERY APPROACH & Characteristics \\
\hline Ainsworth 2011a [83] & Nursing & NS & & & & & & \\
\hline Ainsworth 2011b [83] & Nursing & E & & & & & & \\
\hline $\begin{array}{l}\text { Arroyo-Morales } 2012 \\
\text { [57] }\end{array}$ & Physiotherapy & NS & E & & NS & 46 & Blended learning & $\begin{array}{l}\text { IG: Online tutorial (ECOFISIO) } \\
\text { CG: Self-study }\end{array}$ \\
\hline Baumlin 2000 [58] & Medicine & NS & & & NS & 100 & Blended learning & $\begin{array}{l}\text { IG: Computer Assisted Instructions } \\
\text { (EMCyber-School) } \\
\text { CG: Lectures }\end{array}$ \\
\hline Beeckman 2007[79] & Nursing & E & & & & 426 & Full eLearning & $\begin{array}{l}\text { IG: } 1 \mathrm{~h} \text { eLearning program } \\
\text { CG: } 1 \mathrm{~h} \text { lecture }\end{array}$ \\
\hline Brettle 2013 [53] & Nursing & & NS & & & 77 & Full eLearning & $\begin{array}{l}\text { IG: Online tutorial } \\
\text { CG: } 1 \mathrm{~h} \text { face-to-face tutorial }\end{array}$ \\
\hline Buzzell 2002 [54] & Medicine & NS & & NS & & 34 & $\begin{array}{l}\text { IG1: Full eLearning } \\
\text { IG2: Blended learning }\end{array}$ & $\begin{array}{l}\text { IG: Web-based tutorials } \\
\text { IG2: Traditional lectures with web- } \\
\text { based tutorials } \\
\text { CG: Traditional lectures }\end{array}$ \\
\hline Cantarero2012 [55] & Physiotherapy & & NS & DNT & DNT & 50 & Full eLearning & $\begin{array}{l}\text { IG: Online materials } \\
\text { CG: access to books and documents }\end{array}$ \\
\hline Chen 2007 [81] & Undefined & NS & & & & 145 & $\begin{array}{l}\text { IG1: Full eLearning } \\
\text { IG2: Traditional learning }\end{array}$ & $\begin{array}{l}\text { IG1: A visual advance organizer } \\
\text { IG2: Text outline } \\
\text { CG: Textbook reading without an } \\
\text { advance organizer }(\mathrm{AO})\end{array}$ \\
\hline Chen 2012 [27] & Nursing & $\mathrm{M}$ & & & & 146 & Blended learning & $\begin{array}{l}\text { IG: Online tests } \\
\text { CG: Group A: Paper references, } \\
\text { Group B: No assistance }\end{array}$ \\
\hline$\overline{C o x} 2008$ [28] & Medicine & & DNT & DNT & & 138 & $\begin{array}{l}\text { IG1: Traditional learning } \\
\text { IG2: Blended learning }\end{array}$ & $\begin{array}{l}\text { IG1: Group discussion } \\
\text { IG2: Website, Videos } \\
\text { CG: Paper based, traditional learning } \\
\text { materials }\end{array}$ \\
\hline DeBate 2013 [29] & Dentistry & $\mathrm{T}$ & DNT & NS & & 608 & Full eLearning & $\begin{array}{l}\text { IG: Online (computer and website) } \\
\text { CG: Regular curriculum }\end{array}$ \\
\hline Erickson 2003 [30] & Pharmacy & M & M & & & 42 & $\begin{array}{l}\text { IG1: Traditional learning } \\
\text { IG2: Full eLearning }\end{array}$ & $\begin{array}{l}\text { IG1: Lecture-based tutorial } \\
\text { IG2: Web-based tutorial } \\
\text { CG: No intervention }\end{array}$ \\
\hline Fernandez 2011[76] & Nursing & NS & & & NS & 116 & Full eLearning & $\begin{array}{l}\text { IG: Computer assisted learning } \\
\text { CG: Face-to-Face lecture }\end{array}$ \\
\hline Fleming 2003 [73] & Dentistry & NS & & & NS & 31 & $\begin{array}{l}\text { eLearning and traditional } \\
\text { learning separately }\end{array}$ & $\begin{array}{l}\text { IG: Slide/audiotape self-instruction } \\
\text { and web-based self-instruction } \\
\text { CG: Web-based self-instruction and } \\
\text { slide/audiotape self-instruction }\end{array}$ \\
\hline Flowers 2010 [31] & Pharmacy & E & & & & 79 & Blended learning & $\begin{array}{l}\text { IG: Web-based Multimedia Vignettes } \\
\text { CG: No Web-based Multimedia } \\
\text { Vignettes }\end{array}$ \\
\hline Friedl 2006 [32] & Medicine & NS & DNT & NS & NS & 126 & Full eLearning & $\begin{array}{l}\text { IG: online multimedia course } \\
\text { CG: Text books }\end{array}$ \\
\hline Gerdprasert 2010 [33] & Nursing & NS & E & NS & NS & 84 & Blended eLearning & $\begin{array}{l}\text { IG: Web, interactive graphics, } \\
\text { animation } \\
\text { CG: Traditional teaching }\end{array}$ \\
\hline Hauer 2013 [34] & Medicine & & E & & $E$ & 303 & $\begin{array}{l}\text { IG1: Full eLearning } \\
\text { IG2: Traditional learning }\end{array}$ & $\begin{array}{l}\text { IG: Web based module } \\
\text { CG: Group work, role play. }\end{array}$ \\
\hline Jenkins 2008 [78] & Medicine & NS & & & & 73 & Blended learning & $\begin{array}{l}\text { IG: Internet-based tutorial } \\
\text { CG: Lecture. }\end{array}$ \\
\hline Juliani 2011[25] & Nursing & NS & & & DNT & 80 & Full eLearning & $\begin{array}{l}\text { IG: Designing a schedule with } \\
\text { internet } \\
\text { CG: Designing a schedule without } \\
\text { internet }\end{array}$ \\
\hline Kandasamy 2009 [80] & Medicine & $\mathrm{T}$ & & & NS & 62 & Full eLearning & $\begin{array}{l}\text { IG: Online CAI module } \\
\text { CG: Review articles (Text based) }\end{array}$ \\
\hline Komolpis 2002 [37] & Dentistry & NS & & & NS & 99 & Full eLearning & $\begin{array}{l}\text { IG: Digital records on PC } \\
\text { CG: Hardcopy records }\end{array}$ \\
\hline Lee 2010 [38] & Medicine & NS & & & NS & 52 & Blended learning & $\begin{array}{l}\text { IG: Web-based problems, workshop } \\
\text { CG: No workshop }\end{array}$ \\
\hline Leong 2003 [39] & Medicine & $\mathrm{M}$ & NS & & NS & $\begin{array}{l}54 \text { vs } \\
325^{*}\end{array}$ & $\begin{array}{l}\text { IGI: Full eLearning } \\
\text { IG2: Full eLearning }\end{array}$ & $\begin{array}{l}\text { IG1: Computer based cases (other } \\
\text { than } \mathrm{C} 1+\mathrm{C} 2 \text { ) } \\
\text { IG2: Computer based cases }(\mathrm{C} 1+\mathrm{C} 2) \\
\text { CG: No Computer based cases }\end{array}$ \\
\hline
\end{tabular}


Table 2. continued

\begin{tabular}{|c|c|c|c|c|c|c|c|c|}
\hline Study & Discipune & KNOWLEDGE & SkiLs & Attitude & $\begin{array}{l}\text { Satisfac- } \\
\text { TION }\end{array}$ & $\begin{array}{l}\text { Nlo. of } \\
\text { PARTICIPANTS }\end{array}$ & INTERVENTION DELLUERY APPROACH & Characteristics \\
\hline Lewis 2011 [40] & Medicine & $\mathrm{T}$ & & & NS & 39 & Blended learning & $\begin{array}{l}\text { IG: Web-based MCQ's } \\
\text { CG: Textbook resource }\end{array}$ \\
\hline Lipman 2001[41] & Medicine & E & & & NS & 130 & Blended learning & $\begin{array}{l}\text { IG: Website, books } \\
\text { CG: Books, discussions }\end{array}$ \\
\hline Lu 2009 [42] & Nursing & NS & $E$ & & & 147 & Blended learning & $\begin{array}{l}\text { IG: Lectures and interactive web- } \\
\text { based course } \\
\text { CG: lectures only }\end{array}$ \\
\hline Maag 2004[43] & Nursing & NS & & NS & NS & 96 & $\begin{array}{l}\text { IG1: Traditional learning } \\
\text { IG2: Blended learning } \\
\text { IG3: Blended learning }\end{array}$ & $\begin{array}{l}\text { IG1: Text and image } \\
\text { IG2: Text and image and animation } \\
\text { IG3: Text, Image, Animation, and } \\
\text { Interactivity } \\
\text { CG: Text modules }\end{array}$ \\
\hline Mahnekn 2010[44] & Medicine & NS & & & & 96 & $\begin{array}{l}\text { IG1: Blended learning } \\
\text { IG2: Blended learning }\end{array}$ & $\begin{array}{l}\text { IG1: eLearning, self } \\
\text { IG2: eLearning, mandatory } \\
\text { CG: No access to eLearning }\end{array}$ \\
\hline Nkenke 2012 [48] & Dentistry & NS & & NS & NS & 42 & Blended learning & $\begin{array}{l}\text { IG: Technology enhanced learning } \\
\text { CG: Didactic lectures, PowerPoint } \\
\text { presentation }\end{array}$ \\
\hline Nkenke 2012 [47] & Dentistry & & & & NS & 42 & Blended learning & $\begin{array}{l}\text { IG: Spaced education } \\
\text { CG: Lectures }\end{array}$ \\
\hline Ochoa 2008 [49] & Medicine & E & & NS & & & Full eLearning & $\begin{array}{l}\text { IG: Web-based interactive program } \\
\text { CG: Traditional text. }\end{array}$ \\
\hline Palmer 2008 [50] & Medicine & NS & & & DNT & 130 & $\begin{array}{l}\text { IG1: Traditional learning } \\
\text { IG2: Blended learning } \\
\text { IG3: Blended learning }\end{array}$ & $\begin{array}{l}\text { IG1: Written case-studies } \\
\text { IG2: Clinical material+interactive } \\
\text { computer-based case studies } \\
\text { IG3: Clinical material+interactive } \\
\text { computer-based case studies }\end{array}$ \\
\hline Peroz 2009 [51] & Dentistry & E & & & NS & 85 & Blended learning & $\begin{array}{l}\text { IG: Online education } \\
\text { CG: PowerPoint, discussions }\end{array}$ \\
\hline Phadtare2009 [52] & $\begin{array}{l}\text { Medicine; } \\
\text { Nursing; } \\
\text { Physiotherapy }\end{array}$ & E & & & E & 48 & Full eLearning & $\begin{array}{l}\text { IG: Online materials } \\
\text { CG: Off-line materials }\end{array}$ \\
\hline Raupach 2009 [59] & Medicine & NS & & & DNT & 148 & Blended learning & $\begin{array}{l}\text { IG: Web-based teaching module } \\
\text { CG: face-to-face traditional lecture }\end{array}$ \\
\hline Raupach 2010 [60] & Medicine & E & & & E & 74 & Blended learning & $\begin{array}{l}\text { IG: Web-based module } \\
\text { CG: Traditional lecture }\end{array}$ \\
\hline Ricks 2008 [77] & Medicine & E & & & & 23 & Full eLearning & $\begin{array}{l}\text { IG: Computer Assisted Learning } \\
\text { group } \\
\text { CG: No intervention }\end{array}$ \\
\hline Smits 2012 [64] & Medicine & NS & & $\mathrm{T}$ & NS & 128 & Full eLearning & $\begin{array}{l}\text { IG: Case based eLearning } \\
\text { CG: Text based learning }\end{array}$ \\
\hline Spikard 2002 [65] & Medicine & NS & & & E & 95 & Full eLearning & $\begin{array}{l}\text { IG: Online lecture } \\
\text { CG: Traditional learning }\end{array}$ \\
\hline Stain 2005 [67] & Medicine & NS & & & & 12 vs $98^{*}$ & Full eLearning & $\begin{array}{l}\text { IG: Videoconference lectures } \\
\text { CG: Conventional lectures }\end{array}$ \\
\hline Stewart 2013 [68] & Medicine & & DNT & & NS & 71 & Blended learning & $\begin{array}{l}\text { IG: Online access to learning content } \\
\text { CG: Standard content }\end{array}$ \\
\hline Stolz 2012 [69] & Medicine & NS & $\mathrm{T}$ & & $\mathrm{T}$ & 129 & Full eLearning & $\begin{array}{l}\text { IG: Web-based training } \\
\text { CG: Lectures }\end{array}$ \\
\hline $\begin{array}{l}\text { Subramanian } 2012 \\
\text { [70] }\end{array}$ & Medicine & E & & & & 33 & Full eLearning & $\begin{array}{l}\text { IG: Interactive medical software } \\
\text { CG: Lectures }\end{array}$ \\
\hline Succar 2010 [82] & Medicine & DNT & & & NS & 147 & Blended learning & $\begin{array}{l}\text { IG: Computer based training } \\
\text { CG: Traditional teaching }\end{array}$ \\
\hline Toumas 2009 [71] & Pharmacy & & $E$ & & & 236 & Blended learning & $\begin{array}{l}\text { IG: Internet-based Tutorial } \\
\text { CG: Small group workshop }\end{array}$ \\
\hline Truncali 2011 [72] & Medicine & E & E & DNT & & 141 & Blended learning & $\begin{array}{l}\text { IG: Web-based Tutorial } \\
\text { CG: Lectures }\end{array}$ \\
\hline Wang 2009 [56] & Nursing & E & & NS & & 133 & Blended learning & $\begin{array}{l}\text { IG: Online, self-learning } \\
\text { CG: Traditional multimedia lecture }\end{array}$ \\
\hline Yeung 2013 [75] & Medicine & NS & & & NS & 78 & Blended learning & $\begin{array}{l}\text { IG: Computer-assisted learning } \\
\text { CG: Text-/image-based learning } \\
\text { (TBL) }\end{array}$ \\
\hline
\end{tabular}

E - Results favoured online eLearning over traditional learning, NS - No significant difference between online eLearning and traditional learning, MCQ - Multiple choice questions M - Mixed results, T - Results favoured traditional learning over online eLearning, DNT - Difference not tested, CG - Control group, IG - Intervention group

*Average number students exposed to videoconference lectures and conventional lectures, respectively. 
Student satisfaction was assessed in 28 RCTs [25,32$34,37-41,43,47,48,50-52,55,57,59,60,64,65,68,69,73$, 75,76,80,82] and 1 cRCT [58].

Out of 29 studies looking at the level of student satisfaction, $4[34,52,60,65]$ (14\%) found a significantly greater proportion of students exposed to online eLearning who were satisfied compared to those exposed to traditional learning. One of these 4 studies [60] compared blended learning with traditional learning, whilst the other $3[34,52,65]$ used full eLearning interventions compared with traditional learning ones. Twenty studies (74\%) did not detect any significant difference $[32,33,37-41,43,47,48,51,57,58,64,68,74-$ $76,80,82]$ while in 4 studies satisfaction was assessed $[25,50,55,59]$ but not tested for statistically significant differences between the intervention groups.

There was 1 study [69] using full online eLearning as the main intervention that reported a statistically significant better student satisfaction in the traditional learning group.

\section{Comparison of different types of eLearning against each other}

Ten (18\%) of the included studies [26,35,36,45,46,61$63,66,74]$ compared the effectiveness of various modes of online eLearning against each other. Eight of these studies [26,35,45,46,61-63,74] compared groups of eLearning with different levels of student interaction. In 2 of them "interactivity" was also facilitated by collaborative tools, ie, online web chats [74] and discussion forums and online message systems [61].

Students' knowledge. All of the 10 studies [26,35,36,45,46, 61-63,66,74] comparing various forms of online eLearning measured and reported their effects on knowledge.

Five studies observed a difference in results between different modalities of eLearning. In a study comparing an adaptive form of spaced education against a linear, repetitive one [36], the adaptive eLearning intervention showed better results than its "passive" form. Another study showing significant knowledge acquisition for an "active" eLearning intervention was Chao et al [26] where a linear educational environment (website) supported by complementary information (skin anatomy images) which users could access at will was compared to a non modified website. Similarly, in 1 study [63] an eLearning intervention, allowing students to play a video back and forth at their will showed better knowledge gains in comparison to an eLearning intervention where the procedure was linear. In a study [61] on a "passive" type of eLearning, offering course material through conventional World Wide Web technology and by letting students engage with the instructor only by email resulted in higher knowledge gains in comparison to an interactive eLearning intervention where students could make use of all the learning tools of the Web CT (online proprietary virtual learning environment system) [61]. A "passive" eLearning intervention showed favourable results also for Salas et al [62]. In this study, participants in the "passive" eLearning group were solely provided with a list of random sleep facts and trivia presented in a PowerPoint format. The "active" eLearning intervention consisted of an online, self-paced, sleep medicine learning module.

Non statistical significant differences were found in 4 studies $[35,45,66,74]$ comparing different online eLearning modalities. One study showed no difference in knowledge acquisition between eLearning modes [46].

Students' skills. Skill acquisition was assessed in 1 study [63]. This study showed no significant differences in skills acquisition between the 2 different (active vs passive) eLearning modalities.

Students' attitudes and satisfaction. Manikam et al. [45] and Schittek Janda et al. [63] were the only studies amongst the 10 studies comparing different eLearning modalities that assessed attitude. The study by Manikam et al showed no difference in students' attitudes between the 2 eLearning modes. In this study a dummy learning package was compared to the ABD learning package, ie, symptom-based decision-making pathways software. Schittek Janda et al. reported no significant differences in skills acquisition between the 2 different (active vs passive) eLearning modalities.

Four $(40 \%)$ studies $[46,61,66,74]$ compared the effects of different eLearning modes on student satisfaction. Two studies [46,61] showed no difference in students' satisfaction for the 2 eLearning modes. Frith et al. [74] reported that students in the group that used collaboratively a 6week Web-based course on cardiac rhythm interpretation supported by online chat software were more satisfied than students in the group who worked on the same course independently. In the study by Spickard et al. [66] students in the groups of the online lecture of power point slide presentation with audio narration were more satisfied than students in the group of the online lecture of power point slide presentation without audio narration.

\section{DISCUSSION}

\section{Summary of main results}

This systematic review reports on the effectiveness of online eLearning for undergraduates in health professions. We found that online eLearning does lead to changes in knowledge, skills, attitude and satisfaction and seems to be more effective than traditional learning in terms of knowledge and skills gained. Our findings are similar to previous reviews of online eLearning [21,22,96-100] and offline eLearning [18]. 
In our review, $29 \%$ of the studies showed significantly higher knowledge gains, $40 \%$ of the studies showed significantly greater skill acquisition, $67 \%$ of the studies showed no difference in attitude and 14\% of the studies showed higher satisfaction with online eLearning than traditional learning. The participants in the included studies were from the fields of medicine, dentistry, pharmacy or medical allied studies enrolled at universities, with a smaller number conducted at vocational training centres or colleges. Consequently, the results of this systematic review apply to students from similar disciplines, universities and colleges. The majority of the studies were conducted in high-income countries with exception of few $[25,26,33$, $38,42,52,56,101]$ which were from low to middle income countries, hence these results are generalizable only to their corresponding settings.

The studies included in our review had a high degree of methodological, educational and clinical heterogeneity, similar to previous reports $[21,22,96-100]$. Knowledge assessment was, for example, conducted using different test items or questions [31,70], written case analyses [41], MCQs $[49,51,56,60,72,77]$ the Six-subgroup Quality Scale (SSQS) [52], a general numeracy test [83] and independent assessments. Similarly, there was variability in the assessment of skills, attitudes and satisfaction across the studies. Hence pooling of effect estimates was not possible. Mode of online interventions varied across the studies, most of the studies used a website, while some used other interventions such as spaced education, video lectures or visual concept map. Furthermore, there were great variations in exposure time to the eLearning intervention. Financial and resource related elements of eLearning was reported only in 8 studies $[34,52,54,59,67,68,71,73]$. Nevertheless, none of the studies included a robust costeffectiveness analysis of eLearning vs traditional learning and therefore it is not possible to provide an assessment on cost-effectiveness of online eLearning. Furthermore, no studies reported on the adverse effects of online eLearning.

The overall quality of evidence included in this systematic review is not uniform and contains a significant number of studies with methodological weaknesses with only 1 high quality study [48]; similar findings were reported in previous reviews. [16,19,20,22,102,103] Most of the included studies did not adhere to the CONSORT guidelines for reporting of RCTs [104] and thus their risk of bias was unclear. Several of the included studies had high risk of bias due to volunteer $[49,51,57,60,72,74,83]$ and attrition bias. $[34,41,70,72,79]$. Due to the weaknesses of most of the included studies a strong conclusion on whether there is a clear difference between online eLearning and traditional learning effectiveness that applies to the general population of learners cannot be drawn.
Our study has many strengths. The review was based on a thorough search of available literature which identified a large number of potentially eligible studies identified and synthesized by a multi-disciplinary international team and it offers a number of advantages over previous work in this area. The key strength is an attempt to combine breadth of scope in terms of widely defining eLearning and the range of health professions covered. The review encompasses all empirical studies (RCTs). To ensure data quality, article screening and data extraction was done independently by 2 persons to avoid subjective bias, disagreements were resolved through discussion. The review included studies from both developed and developing countries and thus provides crucial information on the usage, effectiveness and applicability of online eLearning in these settings. Finally, the review used standard methods for systematic reviews and meta-analyses in accordance with preferred reporting items for systematic reviews and meta-analyses (PRISMA) which makes it transparent.

The review had a few limitations. The included studies had several methodological rudiments, we contacted the authors to obtain necessary information for assessing the risk of bias for these studies, however due to time constraints, and it was not possible to contact all authors. Moreover, due to the lack of a uniform, standardized terminology for eLearning studies, we categorized studies as online eLearning (ie, local area network or web-based) and offline eLearning (ie, non-networked or computer based). Although we assigned each individual study to only 1 category, it is important to highlight that there might be some degree of overlap between categories as 1 form of technology may be built on another one.

In summary, this systematic review compares online eLearning and traditional learning in undergraduate healthrelated students and consolidates current knowledge on the effectiveness of online eLearning. The evidence from the highest and the lowest quality studies indicates that online eLearning is equivalent to and perhaps even more effective than traditional learning in terms of knowledge and skills gained. The generalization of these findings is limited only to the studied population in the review.

Online learning's ubiquity provides a convenient and possibly a more cost-effective alternative to traditional learning and has great potential in supporting health care workforce capacity building and competency development globally. This review highlights the need for improvements in the methodological design in future studies.

\section{Implications for policy makers}

The findings of this review present a potential incentive for policy makers to encourage adoption and the development of online eLearning programs. These online eLearning pro- 
grams could be useful in training health care professionals in countries with acute health care worker shortage, without substantial investments. These online technologies if adopted earlier could help lower the burden of diseases by increasing the health care professional per capita. Though adoption of these online technologies would involve some initial start-up cost, it would be largely beneficial as the potential for the return on investment is high in terms of health gains and lives saved.

\section{Implications for educational institutions}

Online eLearning offers many opportunities. This review shows that eLearning is as effective as the traditional learning and with many advantages compared to traditional learning. The universities could adopt these technologies and could reach out to a wider audience within and outside their country, thus offering a tremendous growth opportunity for the educational institutions. Institutions could employ online eLearning to train their health workforce without having to spend for their travel elsewhere within or outside their countries.

\section{Implications for future research}

The findings of the review have many implications for research. Future evaluations of online eLearning should aim to answer many remaining research questions from intervention design features to setting or modality for online eLearning, and build cost-effectiveness models. We should especially aim to strengthen the evidence base for developing countries.

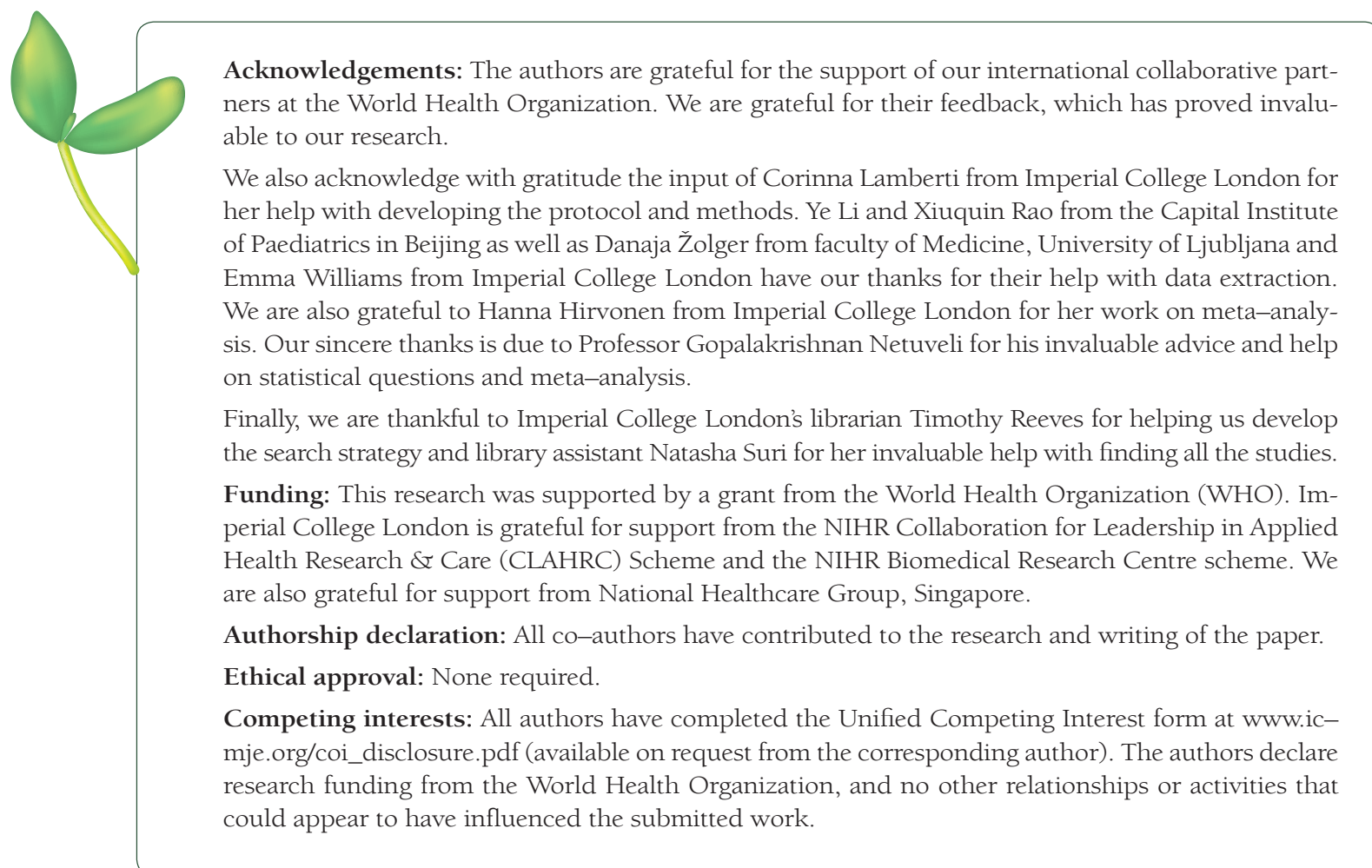

1 Bygbjerg IC. Double burden of noncommunicable and infectious diseases in developing countries. Science. 2012;337:1499-501. Medline:22997329 doi:10.1126/science.1223466

2 Reardon S. A world of chronic disease. Science. 2011;333:558-9. Medline:21798933 doi:10.1126/science.333.6042.558

3 World Health Organization. Global health workforce shortage to reach 12.9 million in coming decades. 2013. Available from: http://www.who.int/mediacentre/news/releases/2013/health-workforce-shortage/en/\#. Accessed: 29 May 2014.

4 Sangrř A, Vlachopoulos D, Cabrera N. Building an inclusive definition of e-learning: an approach to the conceptual framework. Int Rev Res Open Distance Learn. 2012;13:145-59.

5 Masters K, Ellaway R. e-Learning in medical education Guide 32 Part 2: Technology, management and design. Med Teach. 2008;30:474-89. Medline:18576186 doi:10.1080/01421590802108349 
6 Duque G, Demontiero O, Whereat S, Gunawardene P, Leung O, Webster P, et al. Evaluation of a blended learning model in geriatric medicine: A successful learning experience for medical students. Australas J Ageing. 2013;32:103-9. Medline:23773249 doi:10.1111/j.1741-6612.2012.00620.x

7 Makhdoom N, Khoshhal KI, Algaidi S, Heissam K, Zolaly MA. 'Blended learning'as an effective teaching and learning strategy in clinical medicine: a comparative cross-sectional university-based study. Journal of Taibah University Medical Sciences. 2013;8:12-7. doi:10.1016/j.jtumed.2013.01.002

8 Nartker AJ, Stevens L, Shumays A, Kalowela M, Kisimbo D, Potter K. Increasing health worker capacity through distance learning: a comprehensive review of programmes in Tanzania. Hum Resour Health. 2010;8:30. Medline:21194417 doi:10.1186/1478-4491-8-30

9 Rowe M, Frantz J, Bozalek V. The role of blended learning in the clinical education of healthcare students: a systematic review. Med Teach. 2012;34:e216-21. Medline:22455712 doi:10.3109/0142159X.2012.642831

10 Zolfaghari M, Negarandeh R, Eybpoosh S. Developing a blended learning program for nursing and midwifery students in Iran: Process and preliminary outcomes. Iran J Nurs Midwifery Res. 2013;18:20-6. Medline: 23983723

11 UNESCO Institute for Statistics Teachers and educational quality: monitoring global needs for 2015. Vol. 253. UNESCO Inst for Statistics, 2006. Canada: UNESCO Institute for Statistics (UIS), 2006.

12 Andersson A. Seven major challenges for e-learning in developing countries: Case study eBIT, Sri Lanka.elearning. International Journal of Education and Development Using Information and Communication Technology. 2008;4:63-77.

13 Ellis R, Goodyear P. Students' experiences of e-learning in higher education. Oxford: Routledge. 2010.

14 Clarke T, Hermens A. Corporate developments and strategic alliances in e-learning. Educ Train. 2001;43:25667. doi:10.1108/00400910110399328

15 Herrington J, Reeves SFTC, Oliver R. A practical guide to authentic e-learning. Oxford: Routledge, 2010.

16 Potomkova J, Mihal V, Cihalik C. Web-based instruction and its impact on the learning activity of medical students: a review. Biomed Pap Med Fac Univ Palacky Olomouc Czech Repub. 2006;150:357-61. Medline: 17426806 doi: $10.5507 / \mathrm{bp} .2006 .055$

17 Cook DA, Garside S, Levinson AJ, Dupras DM, Montori VM. What do we mean by web-based learning? A systematic review of the variability of interventions. Med Educ. 2010;44:765-74. Medline:20633216 doi:10.1111/j.1365-2923.2010.03723.x

18 Rasmussen K, Wark PA, Molina JA, Loong SL, Cotic Z, Papachristou N, et al. Offline eLearning for undergraduates in health professions: a systematic review of the impact on knowledge, skills, attitudes and satisfaction. J Glob Health. 2013;4:010406. doi: 10.7189/jogh.04.010406

19 Chumley-Jones HS, Dobbie A, Alford CL. Web-based learning: sound educational method or hype? A review of the evaluation literature. Acad Med. 2002;77:S86-93. Medline:12377715 doi:10.1097/00001888200210001-00028

20 Cook DA. Where are we with Web-based learning in medical education? Med Teach. 2006;28:594-8. Medline: 17594549 doi:10.1080/01421590601028854

21 Wutoh R, Boren SA, Balas EA. eLearning: a review of Internet-based continuing medical education. J Contin Educ Health Prof. 2004;24:20-30. Medline:15069909 doi:10.1002/chp.1340240105

22 Curran VR, Fleet L. A review of evaluation outcomes of web-based continuing medical education. Med Educ. 2005;39:561-7. Medline:15910431 doi:10.1111/j.1365-2929.2005.02173.x

23 Higgins JP, Green S. Cochrane handbook for systematic reviews of interventions. London: Wiley Online Library, 2008.

24 UNESCO Institute for Statistics. International Standard Classification of Education, ISCED 2011. Available from: https://www.stat.si/doc/sosvet/Sosvet_19/Sos19_s1925-2013.pdf. Accessed: 30 May 2014.

25 Juliani CMCM, Corrente JE, Dell'Acqua MC. Comparing the teaching-learning process with and without the use of computerized technological resources. Comput Inform Nurs. 2011;29(6 Suppl):TC89-97. Medline: 21701277

26 Chao LW, Enokihara M, Silveira P, Gomes S, Böhm G. Telemedicine model for training non-medical persons in the early recognition of melanoma. J Telemed Telecare. 2003;9 Suppl 1:S4-7. Medline:12952703 doi:10.1258/135763303322196141

27 Chen H-Y, Chuang C-H. The learning effectiveness of nursing students using online testing as an assistant tool: A cluster randomized controlled trial. Nurse Educ Today. 2012;32:208-13. Medline:21450377 doi:10.1016/j. nedt.2011.03.004

28 Cox ED, Koscik RL, Olson CA, Behrmann AT, McIntosh GC, Kokotailo PK. Clinical skills and self-efficacy after a curriculum on care for the underserved. Am J Prev Med. 2008;34:442-8. Medline:18407013 doi:10.1016/j. amepre.2008.01.027

29 DeBate RD, Severson HH, Cragun DL, Gau JM, Merrell LK, Bleck JR, et al. Evaluation of a theory-driven elearning intervention for future oral healthcare providers on secondary prevention of disordered eating behaviors. Health Educ Res. 2013;28:472-87. Medline:23564725 doi:10.1093/her/cyt050

30 Erickson SR, Chang A, Johnson CE, Gruppen LD. Lecture versus Web tutorial for pharmacy students' learning of MDI technique. Ann Pharmacother. 2003;37:500-5. Medline:12659603 doi:10.1345/aph.1C374 
31 Flowers SK, Vanderbush RE, Hastings JK, West D. Web-based multimedia vignettes in advanced community pharmacy practice experiences. Am J Pharm Educ. 2010;74:39. Medline:20498732 doi:10.5688/aj740339

32 Friedl R, Höppler H, Ecard K, Scholz W, Hannekum A, Öchsner W, et al. Multimedia-driven teaching significantly improves students' performance when compared with a print medium. Ann Thorac Surg. 2006;81:17606. Medline:16631668 doi:10.1016/j.athoracsur.2005.09.048

33 Gerdprasert S, Pruksacheva T, Panijpan B, Ruenwongsa P. An interactive web-based learning unit to facilitate and improve intrapartum nursing care of nursing students. Nurse Educ Today. 2011;31:531-5. Medline:21078535 doi:10.1016/j.nedt.2010.10.008

34 Hauer KE, Chou CL, Souza KH, Henry D, Loeser H, Burke C, et al. Impact of an in-person versus web-based practice standardized patient examination on student performance on a subsequent high-stakes standardized patient examination. Teach Learn Med. 2009;21:284-90. Medline:20183354 doi:10.1080/10401330903228307

35 Kerfoot BP. Interactive spaced education versus web based modules for teaching urology to medical students: a randomized controlled trial. J Urol. 2008;179:2351-6. Medline:18423715 doi:10.1016/j.juro.2008.01.126

36 Kerfoot BP. Adaptive spaced education improves learning efficiency: a randomized controlled trial. J Urol. 2010;183:678-81. Medline:20022032 doi:10.1016/j.juro.2009.10.005

37 Komolpis R, Johnson RA. Web-based orthodontic instruction and assessment. J Dent Educ. 2002;66:650-8. Medline: 12056770

38 Lee AM, Groves M, Vlantis AC. Using illness scripts to teach clinical reasoning skills to medical students. Fam Med. 2010;42:255-61. Medline:20373168

39 Leong SL, Baldwin CD, Adelman AM. Integrating Web-based computer cases into a required clerkship: development and evaluation. Acad Med. 2003;78:295-301. Medline:12634211 doi:10.1097/00001888-200303000-00012

40 Lewis EC, Strike M, Doja A, Ni A, Weber J, Wiper-Bergeron N, et al. Web-based software to assist in the localization of neuroanatomical lesions. Can J Neurol Sci. 2011;38:251-5. Medline:21320829

41 Lipman AJ, Sade RM, Glotzbach AL, Lancaster CJ, Marshall MF. The Incremental Value of Internet-based Instruction as an Adjunct to Classroom Instruction: A Prospective Randomized Study. Acad Med. 2001;76:10604. Medline:11597850 doi:10.1097/00001888-200110000-00018

$42 \mathrm{Lu}$ D-F, Lin Z-C, Li Y-J. Effects of a web-based course on nursing skills and knowledge learning. J Nurs Educ. 2009;48:70-7. Medline:19260398 doi:10.3928/01484834-20090201-10

43 Maag M. The effectiveness of an interactive multimedia learning tool on nursing students' math knowledge and self-efficacy. Comput Inform Nurs. 2004;22:26-33. Medline:15069846 doi:10.1097/00024665200401000-00007

44 Mahnken AH, Baumann M, Meister M, Schmitt V, Fischer MR. Blended learning in radiology: Is self-determined learning really more effective? Eur J Radiol. 2011;78:384-7. Medline:21288674 doi:10.1016/j. ejrad.2010.12.059

45 Manikam L, Blackwell N, Banerjee J, Nightingale P, Lakhanpaul M. Improving assessment of paediatric acute breathing difficulties in medical education: a cluster randomized controlled trial. Acta Paediatr. 2013;102:e2059. Medline:23398452 doi:10.1111/apa.12187

46 Mattheos N, Nattestad A, Christersson C, Jansson H, Attström R. The effects of an interactive software application on the self-assessment ability of dental students. Eur J Dent Educ. 2004;8:97-104. Medline:15233773

47 Nkenke E, Vairaktaris E, Bauersachs A, Eitner S, Budach A, Knipfer C, et al. Spaced education activates students in a theoretical radiological science course: a pilot study. BMC Med Educ. 2012;12:32. Medline:22621409 doi:10.1186/1472-6920-12-32

48 Nkenke E, Vairaktaris E, Bauersachs A, Eitner S, Budach A, Knipfer C, et al. Acceptance of technology-enhanced learning for a theoretical radiological science course: a randomized controlled trial. BMC Med Educ. 2012;12:18. Medline:22463757 doi:10.1186/1472-6920-12-18

49 Ochoa JG, Wludyka P. Randomized comparison between traditional and traditional plus interactive Web-based methods for teaching seizure disorders. Teach Learn Med. 2008;20:114-7. Medline:18444196 doi:10.1080/10401330801989513

50 Palmer EJ, Devitt PG. Limitations of student-driven formative assessment in a clinical clerkship. A randomised controlled trial. BMC Med Educ. 2008;8:29. Medline:18471324 doi:10.1186/1472-6920-8-29

51 Peroz I, Beuche A, Peroz N. Randomized controlled trial comparing lecture versus self studying by an online tool. Med Teach. 2009;31:508-12. Medline:19811166 doi:10.1080/01421590802203504

52 Phadtare A, Bahmani A, Shah A, Pietrobon R. Scientific writing: a randomized controlled trial comparing standard and on-line instruction. BMC Med Educ. 2009;9:27. Medline:19473511 doi:10.1186/1472-6920-9-27

53 Brettle A, Raynor M. Developing information literacy skills in pre-registration nurses: An experimental study of teaching methods. Nurse Educ Today. 2013;33:103-9. Medline:22257584 doi:10.1016/j.nedt.2011.12.003

54 Buzzell PR, Chamberlain VM, Pintauro SJ. The effectiveness of web-based, multimedia tutorials for teaching methods of human body composition analysis. Adv Physiol Educ. 2002;26:21-9. Medline:11850324

55 Cantarero-Villanueva I, Fernández-Lao C, Galiano-Castillo N, Castro-Martín E, Díaz-Rodríguez L, ArroyoMorales M. Evaluation of e-learning as an adjunctive method for the acquisition of skills in bony landmark palpation and muscular ultrasound examination in the lumbopelvic region: a controlled study. J Manipulative Physiol Ther. 2012;35:727-34. Medline:23206968 doi:10.1016/j.jmpt.2012.10.007

56 Wang L-F, Wang H-Z, Xiao C-H. Study on the effect of web-based teaching focused on the subject of history of nursing. Chinese Journal of Nursing. 2009;44:729-31. 
57 Arroyo-Morales M, Cantarero-Villanueva I, Fernández-Lao C, Guirao-Pińeyro M, Castro-Martín E, Díaz-Rodríguez L. A blended learning approach to palpation and ultrasound imaging skills through supplementation of traditional classroom teaching with an e-learning package. Man Ther. 2012;17:474-8. Medline:22579034 doi:10.1016/j.math.2012.04.002

58 Baumlin KM, Bessette MJ, Lewis C, Richardson LD. EMCyberSchool An Evaluation of Computer-assisted Instruction on the Internet. Acad Emerg Med. 2000;7:959-62. Medline:10958144 doi:10.1111/j.1553-2712.2000. tb02083.x

59 Raupach T, Muenscher C, Anders S, Steinbach R, Pukrop T, Hege I, et al. Web-based collaborative training of clinical reasoning: a randomized trial. Med Teach. 2009;31:e431-7. Medline:19811180 doi:10.1080/01421590903095502

60 Raupach T, Münscher C, Pukrop T, Anders S, Harendza S. Significant increase in factual knowledge with webassisted problem-based learning as part of an undergraduate cardio-respiratory curriculum. Adv Health Sci Educ Theory Pract. 2010;15:349-56. Medline:19774475 doi:10.1007/s10459-009-9201-3

61 Romanov K, Nevgi A. Learning outcomes in medical informatics: Comparison of a WebCT course with ordinary web site learning material. Int J Med Inform. 2006;75:156-62. Medline:16084757 doi:10.1016/j.ijmedinf.2005.06.004

62 Salas RE, Gamaldo A, Collop NA, Gulyani S, Hsu M, David PM, et al. A step out of the dark: Improving the sleep medicine knowledge of trainees. Sleep Med. 2013;14:105-8. Medline:23127578 doi:10.1016/j. sleep.2012.09.013

63 Schittek Janda M, Tani Botticelli A, Mattheos N, Nebel D, Wagner A, Nattestad A, et al. Computer-mediated instructional video: a randomised controlled trial comparing a sequential and a segmented instructional video in surgical hand wash. EurJ Dent Educ. 2005;9:53-8. Medline:15811151 doi:10.1111/j.1600-0579.2004.00366.x

64 Smits PB, de Graaf L, Radon K, de Boer A, Bos N, van Dijk F, et al. Case-based e-learning to improve the attitude of medical students towards occupational health, a randomised controlled trial. Occup Environ Med. 2012;69:280-3. Medline:22034545 doi:10.1136/oemed-2011-100317

65 Spickard A, Alrajeh N, Cordray D, Gigante J. Learning about screening using an online or live lecture. J Gen Intern Med. 2002;17:540-5. Medline:12133144 doi:10.1046/j.1525-1497.2002.10731.x

66 Spickard A, Smithers J, Cordray D, Gigante J, Wofford JL. A randomised trial of an online lecture with and without audio. Med Educ. 2004;38:787-90. Medline:15200403 doi:10.1111/j.1365-2929.2004.01824.x

67 Stain SC, Mitchell M, Belue R, Mosley V, Wherry S, Adams CZ, et al. Objective assessment of videoconferenced lectures in a surgical clerkship. Am J Surg. 2005;189:81-4. Medline:15701498 doi:10.1016/j.amjsurg.2004.04.012

68 Stewart A, Inglis G, Jardine L, Koorts P, Davies MW. A randomised controlled trial of blended learning to improve the newborn examination skills of medical students. Arch Dis Child Fetal Neonatal Ed. 2013;98:F1414. Medline:22684155 doi:10.1136/archdischild-2011-301252

69 Stolz D, Langewitz W, Meyer A, Pierer K, Tschudi P, S'ng CT, et al. Enhanced Didactic Methods of Smoking Cessation Training for Medical Students-A Randomized Study. Nicotine Tob Res. 2012;14:224-8. Medline:22090454 doi:10.1093/ntr/ntr186

70 Subramanian A, Timberlake M, Mittakanti H, Lara M, Brandt ML. Novel educational approach for medical students: improved retention rates using interactive medical software compared with traditional lecture-based format. J Surg Educ. 2012;69:253-6. Medline:22365876 doi:10.1016/j.jsurg.2011.12.007

71 Toumas M, Basheti IA, Bosnic-Anticevich SZ. Comparison of small-group training with self-directed internet-based training in inhaler techniques. Am J Pharm Educ. 2009;73:85. Medline:19777100 doi:10.5688/ aj730585

72 Truncali A, Lee JD, Ark TK, Gillespie C, Triola M, Hanley K, et al. Teaching physicians to address unhealthy alcohol use: A randomized controlled trial assessing the effect of a Web-based module on medical student performance. J Subst Abuse Treat. 2011;40:203-13. Medline:21094015 doi:10.1016/j.jsat.2010.09.002

73 Fleming DE, Mauriello S, McKaig R, Ludlow J. A comparison of slide/audiotape and Web-based instructional formats for teaching normal intraoral radiographic anatomy. J Dent Hyg. 2003;77:27-35. Medline:12704967

74 Frith KH, Kee CC. The effect of communication on nursing student outcomes in a web-based course. J Nurs Educ. 2003;42:350-8. Medline:12938897

75 Yeung JC, Fung K, Wilson T. Prospective evaluation of a web-based three-dimensional cranial nerve simulation. J Otolaryngol Head Neck Surg. 2012;41:426-36. Medline:23700589

76 Fernández Alemán JL, Carrillo de Gea JM, Rodríguez Mondéjar JJ. Effects of competitive computer-assisted learning versus conventional teaching methods on the acquisition and retention of knowledge in medical surgical nursing students. Nurse Educ Today. 2011;31:866-71. Medline:21255880 doi:10.1016/j.nedt.2010.12.026

77 Ricks C, Ratnapalan S, Jain S, Tait G. Evaluating computer-assisted learning for common pediatric emergency procedures. Pediatr Emerg Care. 2008;24:284-6. Medline:18496110 doi:10.1097/PEC.0b013e31816ecb5c

78 Jenkins S, Goel R, Morrell DS. Computer-assisted instruction versus traditional lecture for medical student teaching of dermatology morphology: a randomized control trial. J Am Acad Dermatol. 2008;59:255-9. Medline:18499299 doi:10.1016/j.jaad.2008.04.026

79 Beeckman D, Schoonhoven L, Boucqué H, Van Maele G, Defloor T. Pressure ulcers: e-learning to improve classification by nurses and nursing students. J Clin Nurs. 2008;17:1697-707. Medline:18592624 doi:10.1111/ j.1365-2702.2007.02200.x 
80 Kandasamy T, Fung K. Interactive Internet-based cases for undergraduate otolaryngology education. Otolaryngol Head Neck Surg. 2009;140:398-402. Medline:19248951 doi:10.1016/j.otohns.2008.11.033

81 Chen B. Effects of advance organizers on learning and retention from a fully Web-based class. Orlando, Florida: University of Central Florida Orlando, 2007.

82 Succar T, Grigg J. A new vision for teaching ophthalmology in the medical curriculum: The Virtual Ophthalmology clinic. In Steel CH, Keppell MJ, Gerbic P, Housego S, eds. Curriculum, technology \& transformation for an unknown future. Proceedings ascilite Sydney 2010. pp.944-7.

83 Ainsworth H, Gilchrist M, Grant C, Hewitt C, Ford S, Petrie M, et al. Computer-based instruction for improving student nurses' general numeracy: is it effective? Two randomised trials. Educ Stud. 2012;38:151-63. doi: $10.1080 / 03055698.2011 .598668$

84 McMullan M, Jones R, Lea S. The effect of an interactive e-drug calculations package on nursing students' drug calculation ability and self-efficacy. Int J Med Inform. 2011;80:421-30. Medline:21470906 doi:10.1016/j.ijmedinf.2010.10.021

85 Tunuguntla R, Rodriguez O, Ruiz JG, Qadri SS, Mintzer MJ, Van Zuilen MH, et al. Computer-based animations and static graphics as medical student aids in learning home safety assessment: A randomized controlled trial. Med Teach. 2008;30:815-7. Medline:18946826 doi:10.1080/01421590802263508

86 Crombie T, Frank JR, Noseworthy S, Gerein R, Lee AC. Teaching emergency medicine skills: is a self-directed, independent, online curriculum the way of the future? Can J Emerg Med. 2012;14 S1:5430.

87 Pancheri KK. Interface design and student satisfaction within online nursing education: A randomized controlled trial. Houston: Texas Woman's University, 2009.

88 Schilling K. The efficacy of eLearning for information-retrieval skills in medical education. 11th European Conference on e-Learning - ECEL 2012. University of Groningen, Groningen, The Netherlands, 26-27 October 2012. p. 515.

89 Duran P, Font R, Kalynych C, Kumar V, Landmann R. 71 Integration of asynchronous ultrasonographic education into a 4-week medical student emergency medicine clerkship: A pilot program. Ann Emerg Med. 2012;60:S186-7. doi:10.1016/j.annemergmed.2012.07.094

90 Duggan PM, Palmer E, Devitt P. Electronic voting to encourage interactive lectures: a randomised trial. BMC Med Educ. 2007;7:25. Medline:17655773 doi:10.1186/1472-6920-7-25

91 Kerfoot BP, Baker H, Jackson TL, Hulbert WC, Federman DD, Oates RD, et al. A multi-institutional randomized controlled trial of adjuvant Web-based teaching to medical students. Acad Med. 2006;81:224-30. Medline:16501262 doi:10.1097/00001888-200603000-00004

92 Kerfoot BP, Conlin PR, Travison T, McMahon GT. Web-based education in systems-based practice: A randomized trial. Arch Intern Med. 2007;167:361-6. Medline:17325297 doi:10.1001/archinte.167.4.361

93 Roberts C, Lawson M, Newble D, Self A, Chan P. The introduction of large class problem-based learning into an undergraduate medical curriculum: an evaluation. Med Teach. 2005;27:527-33. Medline:16199360 doi:10.1080/01421590500136352

94 Turner MK, Simon SR, Facemyer KC, Newhall LM, Veach TL. Web-based learning versus standardized patients for teaching clinical diagnosis: A randomized, controlled, crossover trial. Teach Learn Med. 2006;18:208-14. Medline:16776607 doi:10.1207/s15328015tlm1803_4

95 Jang KS, Hwang SY, Park SJ, Kim YM, Kim MJ. Effects of a Web-based teaching method on undergraduate nursing students' learning of electrocardiography. J Nurs Educ. 2005;44:35-9. Medline:15673173

96 Adler MD, Johnson KB. Quantifying the literature of computer-aided instruction in medical education. Acad Med. 2000;75:1025-8. Medline:11031152 doi:10.1097/00001888-200010000-00021

97 Bernard RM, Abrami PC, Lou Y, Borokhovski E, Wade A, Wozney L, et al. How does distance education compare with classroom instruction? A meta-analysis of the empirical literature. Rev Educ Res. 2004;74:379-439. doi:10.3102/00346543074003379

98 Childs S, Blenkinsopp E, Hall A, Walton G. Effective e-learning for health professionals and students-barriers and their solutions. A systematic review of the literature-findings from the HeXL project. Health Info Libr J. 2005;22 Suppl 2:20-32. Medline:16279973 doi:10.1111/j.1470-3327.2005.00614.x

99 Cook DA, Levinson AJ, Garside S, Dupras DM, Erwin PJ, Montori VM. Internet-based learning in the health professions: a meta-analysis. JAMA. 2008;300:1181-96. Medline:18780847 doi:10.1001/jama.300.10.1181

100 Coomey M, Stephenson J. Online learning: it is all about dialogue, involvement, support and control-according to the research. London: Kogan Page, 2001.

101 Cheng YC, Tam WM. Multi-models of quality in education. Qual Assur Educ. 1997;5:22-31. doi:10.1108/09684889710156558

102 Hammoud M, Gruppen L, Erickson SS, Cox SM, Espey E, Goepfert A, et al. To the point: reviews in medical education online computer assisted instruction materials. Am J Obstet Gynecol. 2006;194:1064-9. Medline:16580297 doi:10.1016/j.ajog.2005.08.023

103 Wutoh R, Boren SA, Balas EA. eLearning: a review of Internet-based continuing medical education. J Contin Educ Health Prof. 2004;24:20-30. Medline:15069909 doi:10.1002/chp.1340240105

104 Schulz KF, Altman DG, Moher D. CONSORT 2010 statement: updated guidelines for reporting parallel group randomized trials. Ann Intern Med. 2010;152:726-32. Medline:20335313 doi:10.7326/0003-4819-152-11201006010-00232 